\title{
Serum levels of bioactive IGF1 and physiological markers of ageing in healthy adults
}

\author{
Poul Frølund Vestergaard ${ }^{1,2}$, Mette Hansen ${ }^{3}$, Jan Frystyk ${ }^{1,2}$, Ulrick Espelund ${ }^{1,2}$, \\ Jens S Christiansen ${ }^{1,2}$, Jens Otto Lunde Jørgensen ${ }^{1,2}$ and Sanne Fisker ${ }^{1,2}$ \\ ${ }^{1}$ Department of Endocrinology and Internal Medicine, Aarhus University Hospital, Nørrebrogade 44, DK-8000 \\ Aarhus C, Denmark, ${ }^{2}$ Medical Research Laboratory, Department of Clinical Medicine, Faculty of Health and ${ }^{3}$ Section \\ of Sport Science, Department of Public Health, Aarhus University, DK-8000 Aarhus C, Denmark
}

\author{
Correspondence \\ should be addressed to \\ P F Vestergaard \\ Email \\ poulv@ki.au.dk
}

\begin{abstract}
Objective: Senescent changes in body composition and muscle strength are accompanied by reduced production of GH and IGF1, but the causal relationship remains elusive. We speculate that serum bioactive IGF1, measured by the IGF1 kinase receptor activation assay, is closer related to human physiological ageing than total IGF1 measured by immunoassay. Design: We conducted a cross-sectional study in 150 adult males and females, between 20 and 70 years. After an overnight fasting, serum levels of bioactive IGF1, total IGF1 and IGF-binding protein 1 (IGFBP1) and IGFBP3 were assessed. Furthermore, body composition and muscle strength was measured.

Results: Total IGF1 levels were higher in females $(P=0.048)$. Bioactive IGF1 were identical in males and females $(P=0.31)$, decreasing with age. Total IGF1 tended to decrease more with age compared with bioactive IGF1 ( -1.48 vs -0.89 percent/year, $P=0.052)$. Total body fat (TBF) was lower and BMI was higher in males $(P<0.001$ and $P=0.005)$, and both increased with age. Knee extension and elbow flexion force were higher in males $(P=0.001$ and $P=0.001)$, but decreased with age in both genders.

Total but not bioactive IGF1 was positively correlated to TBF, knee extension and muscle function in males. In multiple linear regression, only age predicted total IGF1, whereas age and IGFBP1 predicted bioactive IGF1.

Conclusions: Bioactive IGF1 tends to decrease to a lesser extent than total IGF1 with age and was not correlated with measures of body composition or muscle strength. Therefore, levels of circulating bioactive IGF1 does not appear to be a better biomarker of physiological ageing than total IGF1.
\end{abstract}

\section{Introduction}

Ageing is accompanied by changes in body composition and deterioration of muscle quantity and quality. Crosssectional studies have reported a $27 \%$ reduction in lean body mass from 25 to 70 years of age $(1,2)$, whereas knee strength declines with almost $10 \%$ per decade after the fourth decade $(3,4)$. This age-related loss of muscle mass and function seems attributed to various factors, including a decline in muscle fibre size, impairment of muscle cell mitochondrial capacity and induction of apoptosis (5). These alterations are accompanied by a significant age-related decline in the circulating levels of growth hormone $(\mathrm{GH})$ and insulin-like growth factor 1 (IGF1) $(6,7)$, but whether this is causally linked to body composition and muscle strength remains elusive.

$\mathrm{GH}$ is a pituitary hormone secreted primarily in short bursts during sleep, in response to exercise and fasting $(8,9)$. It is well-known that $\mathrm{GH}$ promotes lipolysis and fat oxidation, and that administration of exogenous $\mathrm{GH}$ exerts protein anabolic effects in GH-deficient subjects (10). GH deficiency (GHD) is associated with increased fat 
mass, reduced lean body mass (11) and reduced muscle strength (12), and long-term GH administration to GHD patients is able to normalise body composition and functional capacity (13). By contrast, GH administration to healthy elderly subjects improves neither muscle mass nor function (14), but instead stimulates collagen synthesis in the skeletal muscle (15).

IGF1 is an important downstream mediator of the anabolic effects of GH and its serum levels are inversely correlated with age, with a small difference between sexes $(16,17)$. Moreover, total IGF1 levels are associated with strength, mobility and mortality in women $(18,19)$. The production of $\mathrm{GH}$ is three times higher in women compared with men, despite the fact that circulating IGF1 concentrations are only marginally higher in women (20)), which indicates a relative GH resistance in women. As the decline in muscle strength is identical for both males and females, it is plausible that changes in IGF1 are more closely coupled to the age-related deterioration of skeletal muscle function than $\mathrm{GH}$.

An IGF1 kinase receptor activation (KIRA) assay has been developed for measuring the fraction of serum IGF1 which is able to activate (i.e. phosphorylate) the IGF1 receptor (IGF1R) in vitro (i.e. bioactive IGF1) (21). Subsequent studies have demonstrated that bioactive IGF1 is inversely correlated with age (22), significantly higher in females compared with males (23), and positively correlated with IGF1 as measured by immunoassay (i.e. total IGF1). However, the precise relation between bioactive IGF1 and indices of skeletal muscle mass and function has only sparsely been studied. Accordingly, the aim of this study was to compare serum levels of bioactive IGF1 vs total IGF1 as markers of agerelated changes in muscle strength and body composition.

\section{Subjects and methods}

One hundred and fifty adults (75 males and 75 females) participated in the study. The subjects were divided in age decades from 20 to 70 years, with 15 males and 15 females in each decade. All subjects were healthy, 18 females used contraceptives and two elderly females received hormone replacement therapy. No other medications were used on a regular basis. Blood samples were drawn after an overnight fast. All participants provided written informed consent after receiving written and oral information regarding the study according to the Declaration of Helsinki II. The study was approved by the Local Ethical Committee.
Bioactive IGF1 was determined by the KIRA assay based on human embryonic renal cells (EBNA 293) transfected with the human IGF1R gene (21), with modifications as previously published (24). Total serum IGF1 was determined by time-resolved immunofluorometric assay with modifications as recently published (24). Before assaying, serum was separated by gel chromatography at $\mathrm{pH} 2.7$ in a semi-automated setup. In brief, $100 \mu \mathrm{l}$ serum were incubated with $900 \mu \mathrm{l}$ acetic acid $(1 \mathrm{M})$ for at least $1 \mathrm{~h}$. Hereafter, serum proteins were separated on a column according to size (Superdex 10/300 GL, GE Healthcare, Uppsala, Sweden) using acetic acid $(0.2 \mathrm{M})$ as the eluent. The fraction containing IGF1 was neutralised with a $0.4 \mathrm{M}$ Tris buffer in the microtiter well. A serum control was included for every 20 patient samples and showed a coefficient of variation of $5.9 \%(n=8)$. All samples were assayed in one run. Both IGF1 assays were using the international IGF1 standard (WHO 02/254) as a calibrator (obtained from the National Institute for Biological Standards and Control (NIBSC), Hertfordshire, UK). IGF-binding protein 1 (IGFBP1) was measured by an in-house assay developed and validated by our laboratory (25), as described previously (24).

The estimation of total body fat (TBF) was obtained with the Tanita Body Composition Analyzer BC-418MA (Arlington Heights, IL, USA). The arm muscle area (AMA) was calculated on the basis of Heymsfield's equation using arm circumference and skin fold measurement of the triceps (26). Maximal isometric knee extension and maximal elbow flexion (EF) strength were measured on the Metitur isometric muscle strength device (Metitur, Jyväskylä, Finland). Grip strength was measured with Jamar Hydraulic Hand Dynamometer (Patterson Medical, Bolingbrook, IL, USA). Muscle function was expressed as a ratio between $\mathrm{EF}$ and AMA.

\section{Statistical analysis}

A linear regression model was fitted to describe data. The basic model included the following explanatory variables: age (continuous) and gender (categorical). Age was sufficiently explained by a linear expression, i.e. no significant curvature in any of the tested variables. To test if there was a different age effect between women and men, an interaction term between age and sex was added to the model. If not significant $(P>0.10)$, they were removed from the model again. Models were validated with diagnostic plots of residuals, leverage and predicted values. In addition, Pearson's correlation analysis and 

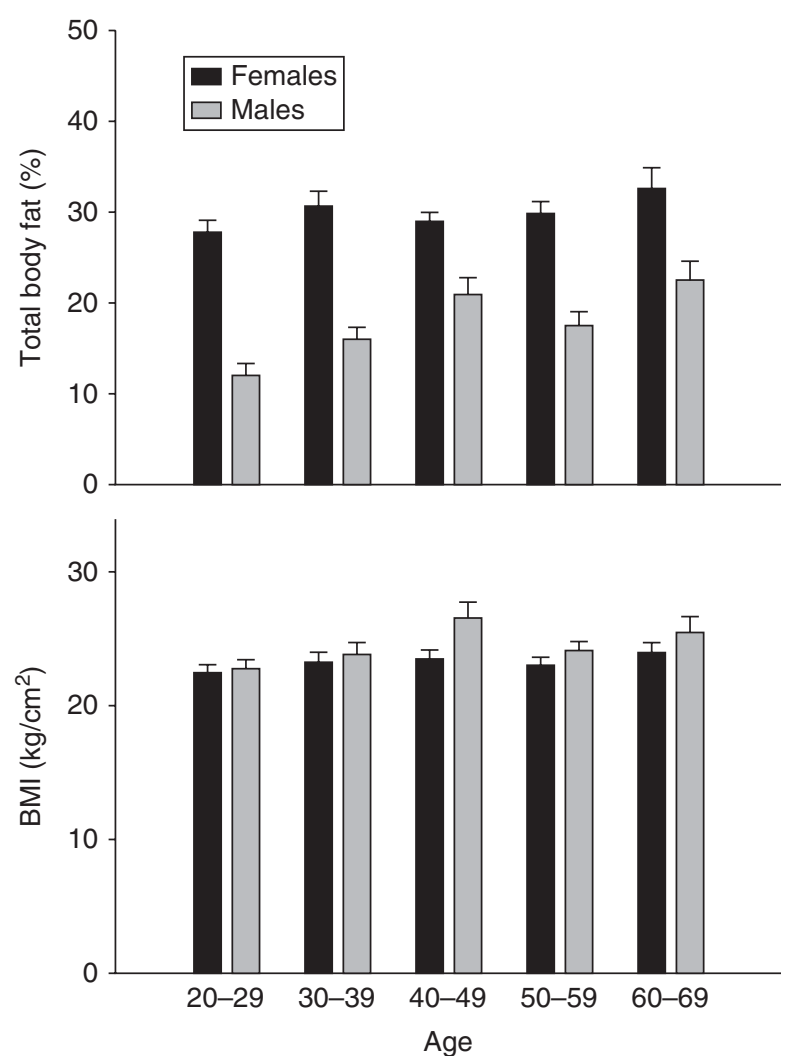

Figure 1

Total body fat and BMI in males (grey) and females (black) in age decades from 20 to 70 years. Mean +s.E.M.

multiple linear regression analyses were applied. The relative changes with age for total and bioactive IGF1 were calculated by dividing the yearly decline with the overall mean of the variable. Data and results are reported as means (95\% CI). $P$ values below 5\% are considered significant. Statistics and figures were produced with Stata Statistical Software, release 12 (StataCorp LP, College Station, TX, USA).

\section{Results}

\section{Body composition}

TBF was lower in males through the entire age range $(P<0.001)$ but increased more with age in males $(0.23$ $(0.13 ; 0.30)$ vs $0.10(0.09 ; 0.19)$, percent/year, $P=0.05)$ (Fig. 1). BMI was higher in males compared with females $(P=0.005)$ and it showed a larger annual increase of 0.05 $(0.01 ; 0.08) \mathrm{kg} / \mathrm{m}^{2}$ per year $(P=0.006)$. There was no interaction between age and gender $(P=0.4)$.

\section{Muscle strength and function}

Knee extension force was higher in males compared with females through the entire age range $(P<0.001)$ despite a more pronounced decrease with age in males than in females $(-5.39(-7.1 ;-3.7)$ vs $-2.7(-4.5 ;-0.9) n /$ year, $P=0.032$ ) (Fig. 2).

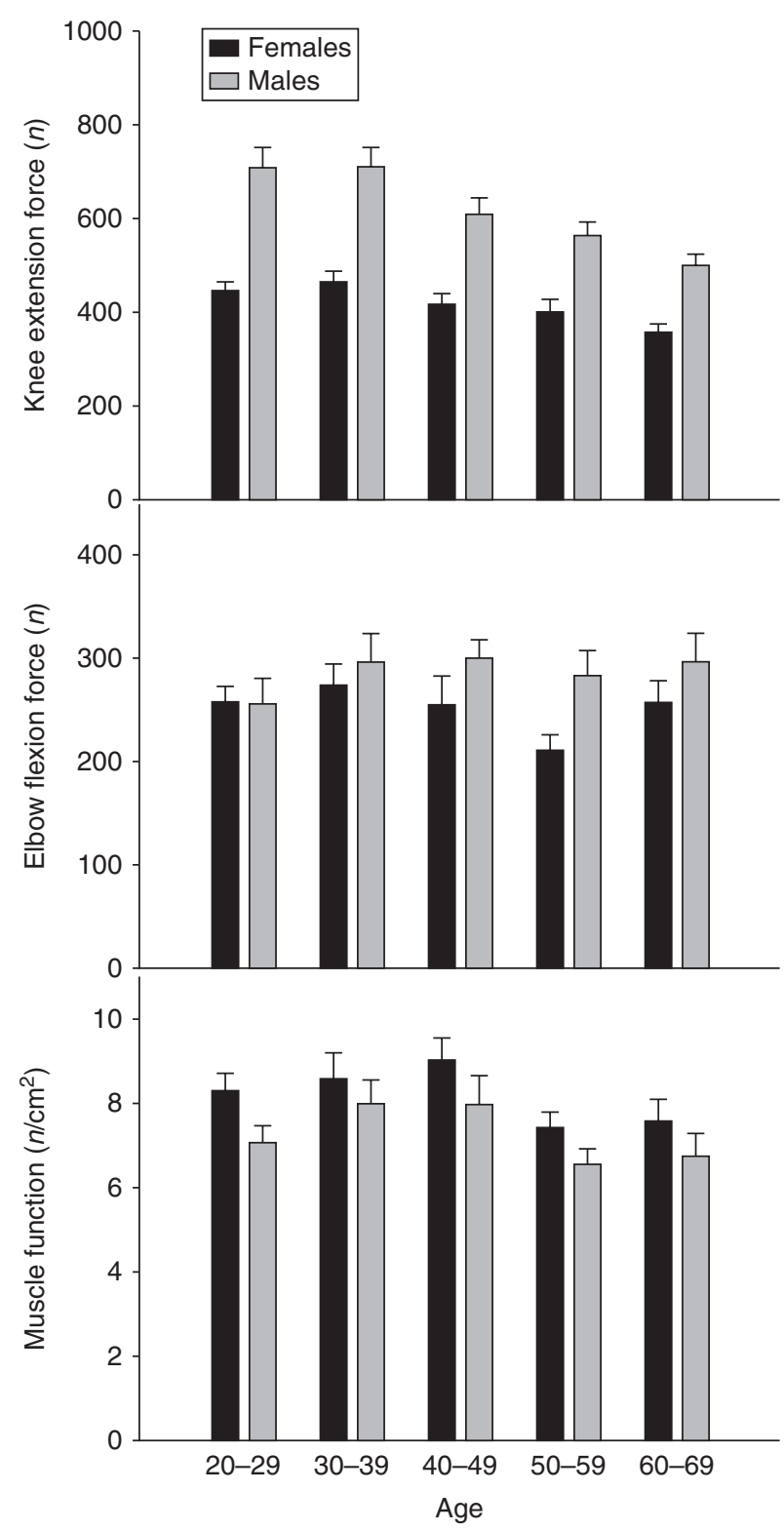

Figure 2

Knee extension force, elbow flexion (EF) force and muscle function (EF force/arm muscle area) in males (grey) and females (black) in age decades from 20 to 70 years. Mean + s.E.M. 

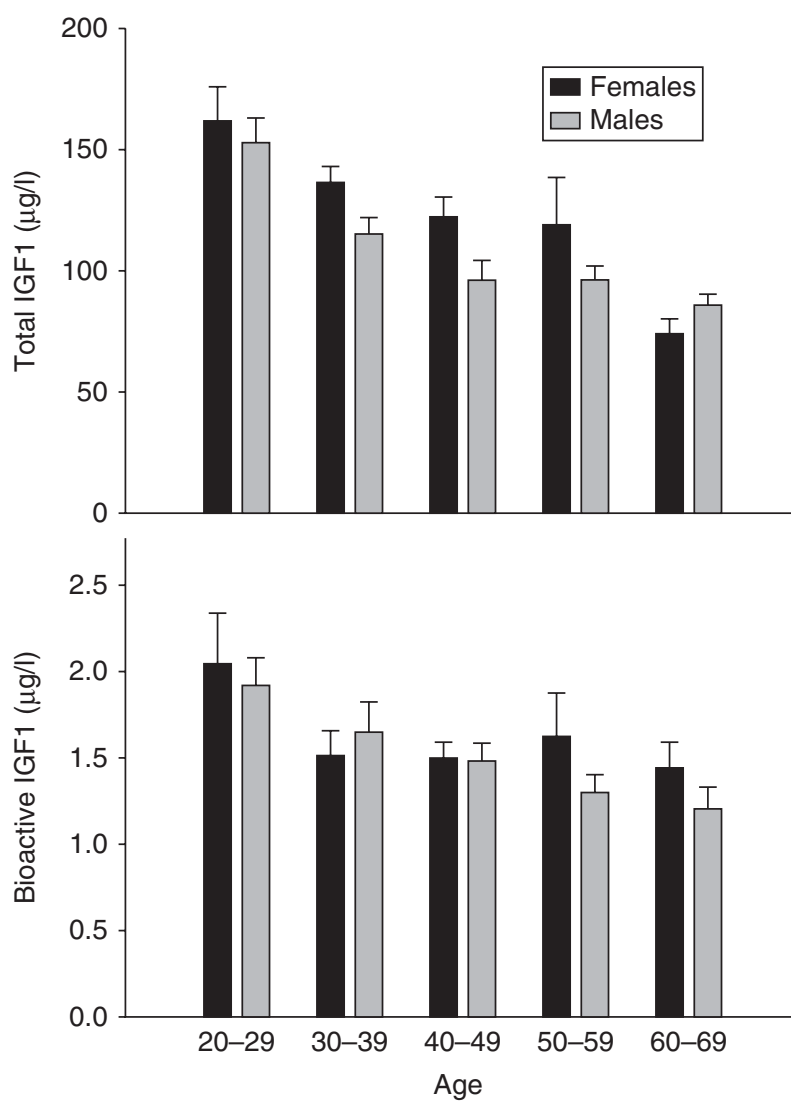

Figure 3

Total and bioactive IGFI in males (grey) and females (black) in age decades from 20 to 70 years. Mean + S.E.M.

EF force was also higher in males compared with females $(P<0.001)$, and again the age-related decrease was more pronounced in males $(-1.8(-2.7 ;-0.9)$ vs $-0.5(-1.4 ;-0.4) n /$ year, $P<0.001)$ than in females. Grip strength was higher in males $(P<0.001)$ and the age-related decrease was $-0.4(-0.6 ; 0.2) n /$ year $(P<0.001)$, with no interaction between age and gender $(P=0.7)$. Muscle function expressed as EF divided by AMA was lower in males compared with females $(P<0.001)$, and the age-related decrease was -0.04 $n / \mathrm{cm}^{2}(-0.05 ;-0.018), P<0.001$, with no interaction between age and gender $(P=0.6)$.

\section{Total IGF1, bioactive IGF1, IGFBP1 and IGFBP3}

Total IGF1 levels were lower in males compared with females $(P=0.048)$, but there was no interaction between age and gender $(P=0.3)$ (Figs 3,4 and 5$)$. In the whole cohort, the annual decrease in total IGF1 was -1.73
$(-2.16 ;-1.30) \mu \mathrm{g} / \mathrm{l}, P<0.001$. The relative age-related decrease in the levels of total IGF1 was $-1.48 \%(-1.84$; -1.11 ) per year.

Bioactive IGF1 levels were identical in males and females $(P=0.31)$ but for total IGF1 we found no interaction between age and gender $(P=0.40)$. In the whole cohort, the annual decrease was $-0.014(-0.021$; $-0.007) \mu \mathrm{g} / \mathrm{l}, \quad P<0.001)$ corresponding to a relative change of $-0.89 \%(-1.36 ;-0.42)$ per year. The relative age-related decrease in the levels of bioactive IGF1 tended to be less pronounced than that of total IGF1, $P=0.052$. Statistically, five subjects (three older and two younger) had levels of bioactive IGF1 above the 95\% CI, of which especially one was higher. For total IGF1, a single subject had an IGF1 level considerably above the 95\% CI. To test the influence of these outliers on the statistical analysis, we excluded them in the comparison of agerelated decrease in bioactive IGF1 and total IGF1, which changed the difference to be significant $(P=0.048)$.

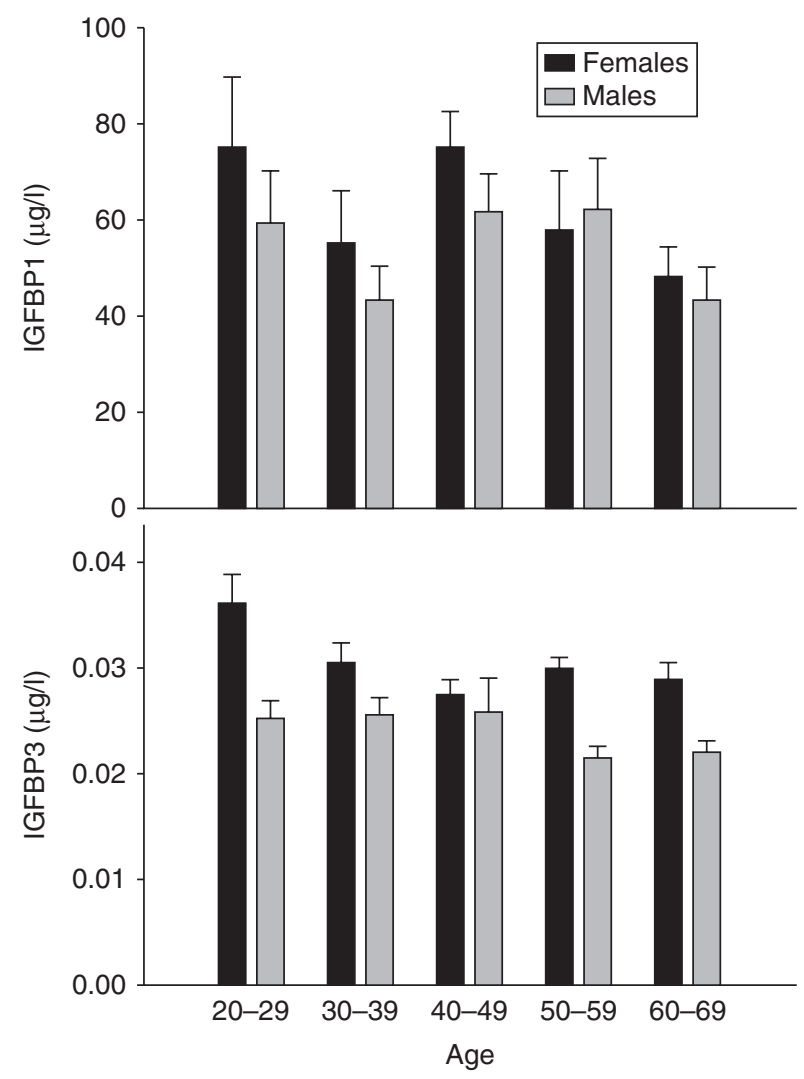

Figure 4

IGFBP1 and IGFBP3 in males (grey) and females (black) in age decades from 20 to 70 years. Mean + S.E.M. 


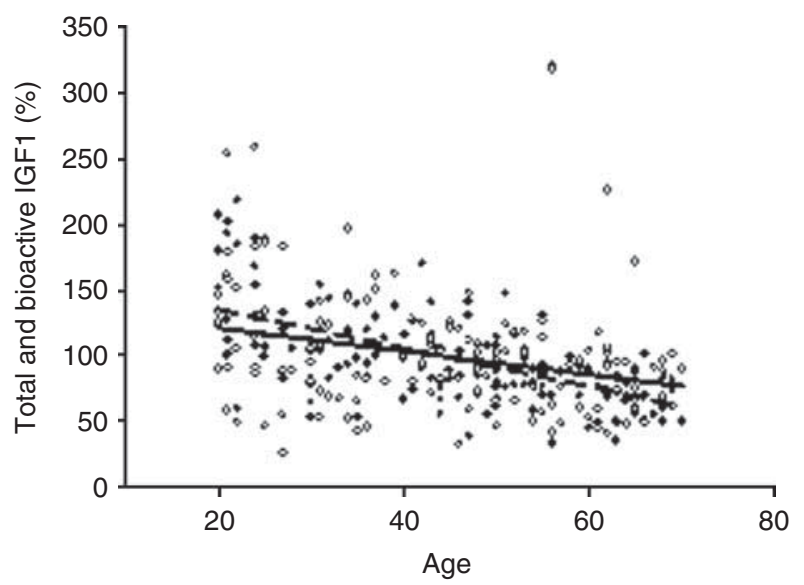

Figure 5

Regression of total and bioactive IGF1 vs age. IGF1 is calculated relative to the levels of a 20-year-old individual (total IGF1, solid line and closed circles; bioactive IGF1, dashed line and open circles).

The levels of IGFBP1 were lower in males compared with females in the age range of 20-54 years, thereafter differences were no longer significant. IGFBP1 decreased with age in females only $(-0.80(-1.4 ;-0.2) \mu \mathrm{g} / \mathrm{l}$ per year, $P=0.006)$.

IGFBP3 levels were lower in males compared with females $(P=0.012)$, with no interaction between age and gender $(P=0.6)$. For the total cohort, the annual decrease was $-24.3(-31.9 ;-16.7) \mu \mathrm{g} / 1, P<0.001$.

\section{Correlation and regression analyses}

Bioactive and total IGF1 levels correlated positively. Total IGF1 correlated positively with TBF, whereas bioactive
IGF1 correlated with neither BMI nor TBF (Table 1). Total IGF1 correlated with knee extension and muscle function, although the latter only in males, whereas bioactive IGF1 did not correlatewith any measure of muscle strength or function.

Multiple linear regression analysis, including measures of body composition, muscle strength, age, gender, IGFBP1 and IGFBP3 as independent variables, showed that only age predicted total IGF1 negatively, whereas age and IGFBP1 both predicted bioactive IGF1 negatively $(P<0.001$ and $P=0.021$ respectively).

\section{Discussion}

The aim of this study was to compare in a cross-sectional design serum levels of bioactive IGF1 and total IGF1 as biomarkers of the age-related changes in muscle strength and body composition in healthy human subjects. We found that levels of bioactive and total IGF1 were positively correlated even though bioactive IGF1 decreased to a lesser extent with age. Bioactive IGF1 was not correlated to any measure of body composition or muscle strength.

It is well-known that serum total IGF concentrations are related with age and several indices of physiological ageing such as body composition, strength, mobility and mortality $(14,16,18,27,28)$. However, the measurement of IGF1 by immunoassay does not take the modifying effect of the IGFBPs on IGF1 action into consideration and therefore we found it relevant to compare total IGF1 and bioactive IGF1 in healthy subjects. We hypothesised that bioactive IGF1 would be more accurately predicted by muscle strength and body composition than total IGF1.

Table 1 Pearson's correlation analysis $(r$ and $P)$.

\begin{tabular}{|c|c|c|}
\hline & Total IGF1 & Bioactive IGF1 \\
\hline \multicolumn{3}{|l|}{ Total IGF1 } \\
\hline Males & & $\begin{array}{c}0.462 \\
P<0.001\end{array}$ \\
\hline Females & & $\begin{array}{c}0.705 \\
P<0.001\end{array}$ \\
\hline \multicolumn{3}{|c|}{ Bioactive IGF1 } \\
\hline Males & $\begin{array}{c}0.462 \\
P<0.001\end{array}$ & \\
\hline Females & $\begin{array}{c}0.705 \\
P<0.001\end{array}$ & \\
\hline \multicolumn{3}{|l|}{ Age } \\
\hline Males & $\begin{array}{c}0.610 \\
P<0.001\end{array}$ & $\begin{array}{c}-0.450 \\
P<0.001\end{array}$ \\
\hline Females & $\begin{array}{c}-0.524 \\
P<0.001\end{array}$ & NS \\
\hline
\end{tabular}

\begin{tabular}{c}
\hline Age \\
\hline-0.610 \\
$P<0.001$ \\
-0.524 \\
$P<0.001$ \\
-0.450 \\
$P<0.001$ \\
NS
\end{tabular}

\begin{tabular}{c}
\hline BMI \\
NS \\
NS \\
NS \\
NS \\
0.270 \\
$P=0.020$ \\
NS
\end{tabular}

\begin{tabular}{|c|}
\hline TBF \\
\hline $\begin{array}{c}0.430 \\
P<0.001 \\
\text { NS }\end{array}$ \\
\hline NS \\
\hline NS \\
\hline $\begin{array}{c}0.503 \\
P=0.001 \\
\text { NS }\end{array}$ \\
\hline
\end{tabular}

\begin{tabular}{c}
\hline $\mathbf{K E}$ \\
\hline \\
0.239 \\
$P=0.039$ \\
0.270 \\
$P=0.019$ \\
NS \\
NS \\
\\
-0.527 \\
$P<0.001$ \\
-0.406 \\
$P<0.001$
\end{tabular}

EF
NS
NS
NS
NS

-0.36
$P=0.001$
NS

\begin{tabular}{c} 
MF \\
\hline $\begin{array}{c}0.255 \\
P=0.029 \\
\text { NS }\end{array}$ \\
NS \\
NS \\
\\
-0.416 \\
$P<0.001$ \\
NS
\end{tabular}

NS, not significant; KE, knee extension force; EF, elbow flexion force; TBF, total body fat; MF, EF/arm muscle area. 
However, in contrast to our expectations, bioactive IGF1 correlated with neither measures of muscle strength nor body composition. In contrast to this, Karl et al. (29) found that bioactive IGF1 correlated inversely with the percentage of body fat determined by dual-energy X-ray absorptiometry in 44 young females. However, in the same study other measures of body composition did not correlate with either IGF1 or bioactive IGF1 (29). Frystyk et al. (30) also found that levels of bioactive IGF1 were unrelated to BMI.

Serum IGFBP1 levels have previously been demonstrated to associate inversely with bioactive IGF1 (31). During haemodialysis a fivefold increase in IGFBP1 was accompanied by a 50\% decrease in bioactive IGF1 despite a marginal reduction in total IGF1 (32). Our data support this finding because we found that IGFBP1 significantly and negatively predicted bioactive IGF1 in multiple linear regression analysis. Although this regression analysis did not identify total IGF1 as a significant predictor of bioactive IGF1, we found that total and bioactive IGF1 were closely related in a correlation analysis and other studies have also demonstrated the positive associations between immunoreactive IGF1 and bioactive IGF1 $(23,33)$.

We analysed data in a group of healthy adults with their age range from 20 to 70 years, who were recruited by advertisement in the local newspaper. This might have induced a selection bias with overrepresentation of trained subjects, in whom relations between IGF1, bioactive IGF1 and physiological markers of ageing are differently affected than less-trained or more frail adult subjects. However, results from longitudinal exercise studies have shown that increases in muscle strength after 8 weeks' training are not accompanied with changes in total IGF1 or bioactive IGF1 (34). We found that total, but not bioactive IGF1, correlated with muscle strength as expressed as knee extension. This leaves the question of whether the levels of bioactive IGF1 are subject to a more complex or subtle regulatory mechanism than total IGF1. Recently published data have suggested that a substance different from the IGFBPs may affect bioactive IGF1, as prednisolone treatment induced a reduction in serum levels of bioactive IGF1 without concomitant changes in the concentrations of IGF1 or the IGFBPs (35).

We observed a higher level of IGF1 in females compared with males, whereas levels of bioactive IGF1 were identical. Both levels of total and bioactive IGF1 were negatively correlated with age. In contrast to our observations, Brugts et al. observed higher levels of bioactive IGF1 in females compared with males until the age of 55 years, whereafter bioactive IGF1 decreased markedly in females resulting in higher levels in males. A decline in bioactive IGF1 related to the menopause was suggested (23). This age-related decrease in bioactive IGF1 in females was not accompanied by a decrease in total serum IGF1 levels. We found identical levels of bioactive IGF1 in males and females through the entire age range. The discrepancy between these findings may to some extent be explained by the blood sampling procedure, as we obtained blood samples after an overnight fast, whereas Brugts et al. took samples from non-fasting blood donors. With respect to IGFBP1 as a carrier of IGF1, overnight fasting may improve comparability of bioactive IGF1 levels between subjects, because IGFBP1 exhibits significant circadian variations (36) depending primarily on insulin fluctuations. Despite significant diurnal variation in binding proteins, levels of bioactive IGF1 do not seem to exhibit significant diurnal variation (30).

The higher levels of total IGF1 in women may be speculated to be secondary to higher levels of its principal carrier IGFBP3. This may also explain why there is no sex difference in bioactive IGF1 in spite of higher levels of total IGF1.

We hypothesised that circulating bioactive IGF1 would be a more sensitive and precise biomarker of agerelated changes in body composition and muscle strength than circulating total IGF1, as the assessment of bioactive IGF1 takes into account factors influencing IGF1 action, in particular IGFBPs. However, our data do not support this statement, which may be explained by the fact that the activity of IGF1 is different in interstitial fluid compared with serum (37). Still, the precise coupling between total IGF1, bioactive IGF1 and muscle strength and body composition, respectively, is not sufficiently elucidated and our data support the view that the relation is complex. We measured circulating levels of total and bioactive IGF1, which mainly reflect IGF1 and IGFBPs produced by the liver. Therefore, the role of interstitial bioactive IGF1 in the peripheral target tissues may be overlooked, because it has been suggested that locally produced IGF1 is of major importance (38). Another limitation of our study is its cross-sectional design.

Overall our data did not support the theory that circulating bioactive IGF1 should be closer related to agerelated changes in muscle strength and body composition than total IGF1. Furthermore, it appears that circulating bioactive IGF1 is regulated by different mechanisms than total IGF1, because the age-related decrease is less pronounced. Future studies of bioactive IGF1 in other compartments may reveal whether local levels of bioactive IGF1 are more powerful biomarkers of age-related changes. 


\section{Declaration of interest}

The authors declare that there is no conflict of interest that could be perceived as prejudicing the impartiality of the research reported.

\section{Funding}

The study was funded by Department of Clinical Medicine, Aarhus University Hospital.

\section{Acknowledgements}

Medical Research Laboratory, Department of Clinical Medicine, Aarhus University Hospital, are thanked for skilled technical assistance with immunoassays, and Mrs Merete Møller is thanked for skilled technical assistance with blood sampling, muscle strength tests and measurements of bioelectrical impedance.

\section{References}

1 Forbes GB \& Reina JC. Adult lean body mass declines with age: some longitudinal observations. Metabolism 197019 653-663. (doi:10.1016/ 0026-0495(70)90062-4)

2 Elmadfa I \& Meyer AL. Body composition, changing physiological functions and nutrient requirements of the elderly. Annals of Nutrition \& Metabolism 200852 2-5. (doi:10.1159/000115339)

3 Kostka T. Quadriceps maximal power and optimal shortening velocity in 335 men aged 23 to 88 years. European Journal of Applied Physiology 200595 140-145. (doi:10.1007/s00421-005-1390-8)

4 Jubrias SA, Odderson IR, Esselman PC \& Conley KE. Decline in isokinetic force with age: muscle cross-sectional area and specific force. Pflügers Archiv: European Journal of Physiology 1997434 246-253. (doi:10. 1007/s004240050392)

5 Wang $\mathrm{CH}, \mathrm{Wu} \mathrm{SB}, \mathrm{Wu}$ YT \& Wei YH. Oxidative stress response elicited by mitochondrial dysfunction: implication in the pathophysiology of aging. Experimental Biology and Medicine 2013238 450-460. (doi:10. 1177/1535370213493069)

6 Rudman D, Kutner MH, Rogers CM, Lubin MF, Fleming GA \& Bain RP. Impaired growth hormone secretion in the adult population: relation to age and adiposity. Journal of Clinical Investigation 198167 1361-1369. (doi:10.1172/JCI110164)

7 Landin-Wilhelmsen K, Lundberg PA, Lappas G \& Wilhelmsen L. Insulin-like growth factor I levels in healthy adults. Hormone Research in Paediatrics 200462 8-16. (doi:10.1159/000080753)

8 Jorgensen JO, Krag M, Kanaley J, Moller J, Hansen TK, Moller N, Christiansen JS \& Orskov H. Exercise, hormones, and body temperature. regulation and action of GH during exercise. Journal of Endocrinological Investigation 200326 838-842.

9 Vendelbo MH, Jorgensen JOL, Pedersen SB, Gormsen LC, Lund S, Schmitz O, Jessen N \& Moller N. Exercise and fasting activate growth hormone-dependent myocellular signal transducer and activator of transcription-5b phosphorylation and insulin-like growth factor-I messenger ribonucleic acid expression in humans. Journal of Clinical Endocrinology and Metabolism 201095 E64-E68. (doi:10.1210/jc.20100689)

10 Bengtsson BA, Eden S, Lonn L, Kvist H, Stokland A, Lindstedt G, Bosaeus I, Tolli J, Sjostrom L \& Isaksson OG. Treatment of adults with growth hormone $(\mathrm{GH})$ deficiency with recombinant human $\mathrm{GH}$. Journal of Clinical Endocrinology and Metabolism 199376 309-317. (doi:10.1210/jc.76.2.309)

11 Salomon F, Cuneo RC, Hesp R \& Sonksen PH. The effects of treatment with recombinant human growth hormone on body composition and metabolism in adults with growth hormone deficiency. New England
Journal of Medicine 1989321 1797-1803. (doi:10.1056/ NEJM198912283212605)

12 Rodriguez A, Jabbar A, Fulcher K, Besser GM \& Ross RJ. Effects of growth hormone replacement on physical performance and body composition in GH deficient adults. Clinical Endocrinology 199951 53-60. (doi:10. 1046/j.1365-2265.1999.00737.x)

13 Carroll PV, Christ ER, Bengtsson BA, Carlsson L, Christiansen JS, Clemmons D, Hintz R, Ho K, Laron Z, Sizonenko P et al. Growth hormone deficiency in adulthood and the effects of growth hormone replacement: a review. Journal of Clinical Endocrinology and Metabolism 199883 382-395. (doi:10.1210/jc.83.2.382)

14 Papadakis MA, Grady D, Black D, Tierney MJ, Gooding GA, Schambelan M \& Grunfeld C. Growth hormone replacement in healthy older men improves body composition but not functional ability. Annals of Internal Medicine 1996124 708-716. (doi:10.7326/0003-4819. 124-8-199604150-00002)

15 Doessing S, Heinemeier KM, Holm L, Mackey AL, Schjerling P, Rennie M, Smith K, Reitelseder S, Kappelgaard AM, Rasmussen MH et al. Growth hormone stimulates the collagen synthesis in human tendon and skeletal muscle without affecting myofibrillar protein synthesis. Journal of Physiology 2010588 341-351. (doi:10.1113/jphysiol.2009. 179325)

16 O'Connor KG, Tobin JD, Harman SM, Plato CC, Roy TA, Sherman SS \& Blackman MR. Serum levels of insulin-like growth factor-I are related to age and not to body composition in healthy women and men. Journals of Gerontology. Series A, Biological Sciences and Medical Sciences 199853 M176-M182. (doi:10.1093/gerona/53A.3.M176)

17 Hilding A, Hall K, Wivall-Helleryd IL, Saaf M, Melin AL \& Thoren M. Serum levels of insulin-like growth factor I in 152 patients with growth hormone deficiency, aged 19-82 years, in relation to those in healthy subjects. Journal of Clinical Endocrinology and Metabolism $1999 \mathbf{8 4}$ 2013-2019. (doi:10.1210/jc.84.6.2013)

18 Taekema DG, Ling CHY, Blauw GJ, Meskers CG, Westendorp RG, de Craen AJ \& Maier AB. Circulating levels of IGF1 are associated with muscle strength in middle-aged- and oldest-old women. European Journal of Endocrinology 2011164 189-196. (doi:10.1530/EJE-10-0703)

19 Kaplan RC, McGinn AP, Pollak MN, Kuller L, Strickler HD, Rohan TE, Xue X, Kritchevsky SB, Newman AB \& Psaty BM. Total insulinlike growth factor 1 and insulinlike growth factor binding protein levels, functional status, and mortality in older adults. Journal of the American Geriatrics Society 200856 652-660. (doi:10.1111/j.1532-5415.2007. 01637.x)

20 Frystyk J, Freda P \& Clemmons DR. The current status of IGF-I assays - a 2009 update. Growth Hormone \& IGF Research 201020 8-18. (doi:10. 1016/j.ghir.2009.09.004)

21 Chen JW, Ledet T, Orskov H, Jessen N, Lund S, Whittaker J, De Meyts P, Larsen MB, Christiansen JS \& Frystyk J. A highly sensitive and specific assay for determination of IGF-I bioactivity in human serum. American Journal of Physiology. Endocrinology and Metabolism 2003284 E1149-E1155. (doi:10.1152/ajpendo.00410.2002)

22 Brugts MP, van den Beld AW, Hofland LJ, van der Wansem K, van Koetsveld PM, Frystyk J, Lamberts SW \& Janssen JA. Low circulating insulin-like growth factor I bioactivity in elderly men is associated with increased mortality. Journal of Clinical Endocrinology and Metabolism 200893 2515-2522. (doi:10.1210/jc.2007-1633)

23 Brugts MP, Ranke MB, Hofland LJ, van der Wansem K, Weber K, Frystyk J, Lamberts SW \& Janssen JA. Normal values of circulating insulin-like growth factor-I bioactivity in the healthy population: comparison with five widely used IGF-I immunoassays. Journal of Clinical Endocrinology and Metabolism 200893 2539-2545. (doi:10.1210/ jc.2007-2454)

24 Reinhard M, Frystyk J, Jespersen B, Bjerre M, Christiansen J, Flyvbjerg A \& Ivarsen P. Effect of hyperinsulinemia during hemodialysis on the insulin-like growth factor system and inflammatory biomarkers: a randomized open-label crossover study. BMC Nephrology 20131480. (doi:10.1186/1471-2369-14-80) 
25 Frystyk J, Hojlund K, Rasmussen KN, Jorgensen SP, WildnerChristensen M \& Orskov H. Development and clinical evaluation of a novel immunoassay for the binary complex of IGF-I and IGF-binding protein-1 in human serum. Journal of Clinical Endocrinology and Metabolism 200287 260-266. (doi:10.1210/jc.87.1.260)

26 Heymsfield SB, McManus C, Smith J, Stevens V \& Nixon DW. Anthropometric measurement of muscle mass: revised equations for calculating bone-free arm muscle area. American Journal of Clinical Nutrition 198236 680-690.

27 Cappola AR, Bandeen-Roche K, Wand GS, Volpato S \& Fried LP. Association of IGF-I levels with muscle strength and mobility in older women. Journal of Clinical Endocrinology and Metabolism 200186 4139-4146. (doi:10.1210/jc.86.9.4139)

28 Unden AL, Elofsson S, Knox S, Lewitt MS \& Brismar K. IGF-I in a normal population: relation to psychosocial factors. Clinical Endocrinology 2002 57 393-803. (doi:10.1046/j.1365-2265.2002.01671.x)

29 Karl JP, Alemany JA, Koenig C, Kraemer WJ, Frystyk J, Flyvbjerg A, Young AJ \& Nindl BC. Diet, body composition, and physical fitness influences on IGF-I bioactivity in women. Growth Hormone \& IGF Research 200919 491-496. (doi:10.1016/j.ghir.2009.04.001)

30 Frystyk J, Brick DJ, Gerweck AV, Utz AL \& Miller KK. Bioactive insulinlike growth factor-I in obesity. Journal of Clinical Endocrinology and Metabolism 200994 3093-3097. (doi:10.1210/jc.2009-0614)

31 Hilding A, Brismar K, Degerblad M, Thorén M \& Hall K. Altered relation between circulating levels of insulin-like growth factor-binding protein-1 and insulin in growth hormone-deficient patients and insulin-dependent diabetic patients compared to that in healthy subjects. Journal of Clinical Endocrinology and Metabolism $1995 \mathbf{8 0}$ 2646-2652. (doi:10.1210/jc.80.9.2646)
32 Ivarsen P, Chen JW, Tietze I, Christiansen JS, Flyvbjerg A \& Frystyk J. Marked reductions in bioactive insulin-like growth factor I (IGF-I) during hemodialysis. Growth Hormone \& IGF Research 201020 156-161. (doi:10.1016/j.ghir.2009.12.001)

33 Frystyk J. Quantification of the GH/IGF-axis components: lessons from human studies. Domestic Animal Endocrinology 201243 186-197. (doi:10.1016/j.domaniend.2011.11.005)

34 Nindl BC, Alemany JA, Tuckow AP, Rarick KR, Staab JS, Kraemer WJ, Maresh CM, Spiering BA, Hatfield DL, Flyvbjerg A et al. Circulating bioactive and immunoreactive IGF-I remain stable in women, despite physical fitness improvements after 8 weeks of resistance, aerobic, and combined exercise training. Journal of Applied Physiology 2010 109 112-120. (doi:10.1152/japplphysiol.00025.2010)

35 Frystyk J, Schou AJ, Heuck C, Vorum H, Lyngholm M, Flyvbjerg A \& Wolthers OD. Prednisolone reduces the ability of serum to activate the IGF-I receptor in vitro without affecting circulating total or free IGF-I. European Journal of Endocrinology 2012168 1-8. (doi:10.1530/EJE-120518)

36 Lee PD, Giudice LC, Conover CA \& Powell DR. Insulin-like growth factor binding protein-1: recent findings and new directions. Proceedings of the Society for Experimental Biology and Medicine 1997216 319-357. (doi:10.3181/00379727-216-44182)

37 Espelund U, Sondergaard K, Bjerring P, Flyvbjerg A \& Frystyk J. Interstitial fluid contains higher in vitro IGF bioactivity than serum: a study utilizing the suction blister technique. Growth Hormone \& IGF Research 201222 234-239. (doi:10.1016/j.ghir.2012.08.002)

38 Yakar S, Liu JL, Stannard B, Butler A, Accili D, Sauer B \& LeRoith D. Normal growth and development in the absence of hepatic insulin-like growth factor I. PNAS 199996 7324-7329. (doi:10.1073/ pnas.96.13.7324)

Received 14 August 2013

Revised version received 9 October 2013

Accepted 31 October 2013 